\title{
UPAYA GURU DALAM MENGINTERNALISASIKAN NILAI-NILAI SIKAP MAJA LABO DAHU PADA ANAK KELAS B TK NEGERI PEMBINA 03 RASANA'E BARAT KOTA BIMA
}

\author{
Afriani Muhlisa, Lukman \\ Mahasiswa Institut Agama Islam (IAI) Muhammadiyah Bima \\ Email: putrasanggar231@gmail.com
}

\section{ABSTRAK}

Penelitian menggunakan jenis penelitian kualitatif dengan pendekatan deskriptif analitik, dengan tekhnik pengumpulan data melalui observasi, wawancara dan dokumentasi. Adapun sumber data penelitian ini yaitu guru/tenaga pendidik dan anak di kelas B1 di Taman Kanak-Kanak (TK) Negeri Pembina 03 Rasana'e Barat Kota Bima. Terkait dengan tekhnik analisis data yang digunakan yaitu reduksi data, penyajian data dan penarikan kesimpulan. Hasil Penelitian menunjukkan bahwa upaya yang dilakukan oleh guru dalam menanamkan nilai sikap Maja labo dahu yaitu dengan memberikan pembiasaan-pembiasaan serta dengan mengarahkan anak sekaligus memberi contoh yang baik bagi anak seperti menghargai sesama dan menghormati orang yang lebih tua, disiplin waktu, mengikuti aturan yang telah ditetapkan sekolah, Imtaq serta menjaga kebersihan lingkungan sekolah. Serta merasa malu dan takut jika melakukan suatu perbuatan yang menyimpang dari ajaran agama. Hingga dapat merugikan diri sendiri dan orang lain. Apapun yang dilakukan oleh manusia selalu dilihat oleh Allah swt. Oleh sebab itu nilai maja labo dahu merupakan alat pengotrol dalam bertindak bagimasyarakat Bima. Metode yang dilakukan oleh guru dalam menanamkan nilai sikap maja labo dahu yaitu tergantung dari pembelajaran yang diberikan dan disesuaikan dengan usia perkembangan anak. Karena di Taman kanak-kanak (TK) Negeri Pembina 03 Rasana'e Barat Kota Bima menggunakan model pembelajaran yang berbasis area, maka setiap area memiliki APE yang dibutuhkan dalam menanamkan nilai sikap maja labo dahu seperti APE tata cara berwudhu dan shalat. Metode yang digunakan ada enam metode yaitu metode bercerita, metode keteladanan, demonstrasi untuk nilai ibadah, metode karyawisata, metode pemberian tugas dan metode pembiasaan. Guru sebagai ibu kedua anak di sekolah setelah ibu yang telah melahirkan mereka merupakan ssalah satu salah satu sumber belajar anak usia dini yang menjadikan mereka sebgai model yang ditiru. Peran guru dalam

Jurnal Pelang̉i Jurnal pemikiran dan penelitian pendidikan Islam anak Usia Dini 
menanamkan nilai kearifan lokal maja labo dahu sebagai falsafah hidup masyarakat Bima (Mbojo) sangat penting sebagai penyaring dan tameng anak dalam bertingkah laku dan bertutur kata sekaligus dijadikan sebagai pedoman dalam kehidupan anak. Tujuan penelitian ini dilakukan untuk mengetahui upaya, usaha dan metode yang dilakukan oleh guru dalam menanamkan sikap Maja labo dahu pada anak di kelas B di Taman KanakKanak (TK) Negeri Pembina 03 Rasana'e Barat Kota Bima.

Kata Kunci: Upaya Guru, Menginternalisasikan Nilai-Nilai, dan Sikap Maja Labo Dahu

\section{PENDAHULUAN}

Derasnya arus globalisasi, modernisasi dikhawatirkan dapat mengakibatkan terkikisnya rasa kecintaan terhadap kebudayaan lokal, sehingga kebudayaan lokal yang merupakan warisan leluhur dilupakan begitu saja oleh para pewarisnya, bahkan banyak pemuda yang tidak mengenali budaya daerahnya sendiri.

Mengenalkan kebudayaan lokal dilakukan sedari dini agar penanaman nilai-nilai budaya yang terkandung didalamnya dapat dipahami serta dijunjung tinggi oleh generasi penerus dan dapat melestarikan kebudayaan lokal itu sendiri.

Anak Usia Dini adalah anak pada rentangan usia 4-6 tahun yang mengikuti pendidikan di Taman Kanak-kanak (TK). Pendidikan di TK merupakan pendidikan prasekolah sebagai wahana untuk menyiapkan anak dari segi sikap, pengetahuan, dan keterampilan guna memasuki sekolah dasar. ${ }^{1}$

Taman kanak-kanak (kindergarten) adalah salah satu bentuk satuan pendidikan Anak Usia Dini pada jalur pendidikan formal yang menyelenggarakan program pendidikan bagi anak usia empat sampai enam tahun ${ }^{2}$.

Secara mendasar bahwa pendidikan dilembaga formal atau sekolah sebagai lembaga pendidikan berfungsi sebagai wahana sosialisasi, membantu anak-anak dalam mempelajari cara-cara hidup

\footnotetext{
${ }^{1}$ Risah Alfiya Ulfah, Internalisasi Nilai-Nilai Kearifan Lokal Melalui Prinsip Pendidikan Berbasis Keunggulan Lokal (Pbkl) Pada Pendidikan Anak Usia Dini, ( Tesis, UIN Sunan Kalijaga Yogyakarta, 2014), hal.209.

${ }^{2}$ Mansur, Pendidikan Anak Usia Dini Dalam Islam, (Pustaka Pelajar : Yogyakarta, 2014), hal.127.
} 
dimana mereka dilahirkan. Sekolah berfungsi mentransmisi dan mentransformasi kebudayaan, mengajarkan nilai-nilai kebudayaan dari generasi tua ke generasi muda. Sekolah berfungsi mentransformasi budaya, artinya untuk mengubah bentuk kebudayaan agar tetap sesuai dengan masyarakat yang semakin maju dan komplek dengan tidak meninggalkan kultur kebudayaan kita. ${ }^{3}$

Kebudayaan suatu bangsa menunjukkan akan adanya corak kehidupan yang berbeda dengan corak kehidupan kepribadian setiap daerah. Hal ini disebabkan oleh lingkungan dan tempat tinggal setiap bangsa yang berbeda. Budaya dapat dilihat oleh masing-masing individu dengan sudut pandang yang berbeda, baik dari ide, nilai, norma perilaku maupun material. ${ }^{4}$

Nilai-nilai luhur itu biasa disebut dengan kearifan lokal (lokal wisdom). Kearifan lokal menurut UU No.32/2009 tentang perlindungan dan pengelolaan lingkungan BAB I pasal 1 butir 30 adalah nilai-nilai luhur yang berlaku dalam kehidupan masyarakat antara lain untuk melindungi dan mengelola lingkungan hidup secara lestari. ${ }^{5}$

Banyak lembaga pendidikan AnakUsia Dini di Bima mulai berkembang, tidak hanya diperkotaan saja, namun dipedesaan dan Kabupatenpun sudah mulai berkembang dengan baik, termasuk Taman Kanak-Kanak (TK) Negeri Pembina 03 Rasana'e Barat Kota Bima. TK Negeri Pembina merupakan TK percontohan yang ada di Kota Bima maupun di Kabupaten Bima, seperti hasil observasi saya pada tanggal 4 Mei 2018 di kelas B, disini anak-anak mulai diajarkan dan ditanamkan nilai Maja Labo Dahu, yaitu Maja (Malu) dan Dahu (takut) melakukan kesalahan dengan mempercayai dosa yang didapat dan hukuman apabila tetap melakukannya. Anak harus malu apabila tidak mengantri dengan baik, malu jika tidak mematuhi perkataan ibu guru di sekolah. Disana anak diajarkan disiplin dalam berbagai hal, seperti dalam hal pakaian, waktu belajar, kebersihan dan lain sebagainya. ${ }^{6}$

Maja Labo Dahu bagi masyarakat Bima pada masa lalu, merupakan warisan budaya yang amat berharga untuk dijadikan pedoman dalam

${ }^{3}$ Ulfah, Inernalisasi Nilai-Nilai...........,hal.208.

${ }^{4}$ Sri Rahayu, Analisis Bentuk, Fungsi, dan Makna Rimpu Sebagai Tradisi Folklor Nonverbal Masyarakat Bima Nusa Tenggara Barat, ( Skripsi ,UMM, Malang, 2014), hal.20.

${ }^{5}$ Ulfah, Inernalisasi Nilai-Nilai............hal.209.

${ }^{6}$ Observasi di TK Negeri Pembina 03 Rasana'e Barat kota Bima pada tanggal 4 Mei 2018

Jurnal Pelang̉i Jurnal pemikiran dan penelitian pendidikan Islam anak Usia Dini 
kehidupan, guna mewujudkan kebahagiaan dunia dan akhirat. Pada masa kesultanan, Maja Labo Dahu menjadi sumber kekuatan bathin, bagi pemerintah dan rakyat dalam mengemban tugas. Mungkin itulah salah satu yang membuat kesultanan Bima mengalami kejayaan pada waktu yang lama. ${ }^{7}$

Jika kita meninjau kata diatas secara semantik atau maknawi, Maja (malu) bermaknakan bahwa orang ataupun masyarakat Bima akan malu ketika melakukan sesuatu diluar daripada koridor Tuhan, apakah itu kejahatan, perbuatan dosa dan lain sebagainya baik yang berhubungan dengan manusia ataupun terhadap Tuhannya. Dahu (takut), hampir memilki proses interpretasi yang sama dengan kata Malu tersebut. Samasama takut ketika melakukan sesuatu kejahatan ataupun keburukan.

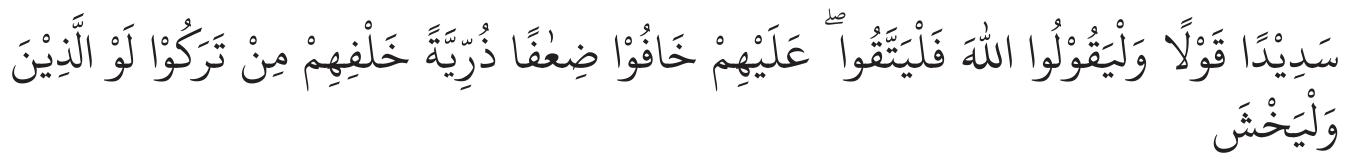

Terjemahannya: Dan hendaklah takut (kepada Allah) orang-orang yang sekiranya mereka meninggalkan keturunan yang lemah di belakang mereka yang mereka khawatir terhadap (kesejahteraan)nya. Oleh sebab itu, hendaklah mereka bertakwa kepada Allah, dan hendaklah mereka berbicara dengan tutur kata yang benar.» (Q.S. An-Nisa> (4): Ayat 9). ${ }^{8}$

Ayat di atas menjelaskan bahwa manusia hendaklah takut (takwa) kepada Allah apabila manusia meninggalkan keturunan yang lemah akan iman dan ketakwaan kepada Allah, dan berbicara dengan tutur kata yang sopan dan benar. Dalam hal ini nilai maja labo dahu terlihat pada ketakwaan yang telah disebutkan diatas dan malu dalam hal tidak berbicara dengan sopan dan santun.

Dilihat dari banyaknya keberadaan PAUD dikalangan masyarakat Bima, mampu menyadarkan masyarakat akan pentingnya pendidikan awal sebagai pondasi bagi anak untuk kejenjang berikutnya. Berkaitan dengan hal tersebut, nilai luhur dan budaya daerahpun tetap harus dikenalkan pada anak agar mereka lebih mengenal dan menghargai warisan budaya.

${ }^{7}$ Djamaluddin Sahidu, Kampung Orang Bima, (Mataram : Studio 15, 2008), hal.51.

${ }^{8}$ QS. An-Nisa' (4): Ayat 9) 
Dalam melindungi kebudayaan lokal yang kian tergerus, perlu di lakukan penguatan akan budaya yang ada di daerah melalui pembelajaran yang aktif dan kreatif bagi anak serta mengandung nilai-nilai budaya dan bukti sejarah agar generasi penerus tidak meninggalkan dan melupakan budaya sendiri yang ada di daerah.

\section{KONSEP GURU}

\section{Pengertian Guru}

Guru adalah orang yang pekerjaan, mata pencaharian dan profesinya adalah mengajar. ${ }^{9}$ Dalam Undang-undang Nomor 14 Tahun 2005 tentang guru dan dosen Bab 1 pasal 1 ayat (1) mendefinisikan bahwa guru adalah pendidik profesional dengan tugas utama mendidik, mengajar, membimbing, mengarahkan, melatih, menilai dan mengevaluasi peserta didik pada pendidikan anak usia dini jalur pendidikan formal, pendidikan dasar dan pendidikan menengah. ${ }^{10}$

Zainal aqib mengemukakan bahwa seorang guru adalah seorang ahli dalam bidangnya, memiliki kecakapan pengetahuan akademis, juga kecakapan sosial, dan spritual, sehingga bisa membawa murid kearah perkembangan yang benar. ${ }^{11}$ Dengan demikian dapat dikatakan bahwa guru adalah adalah pendidik profesional dalam bidangnya dengan tugas utama mendidik, mengajar, membimbing, mengarahkan, melatih, menilai dan mengevaluasi peserta didik yang memiliki kecakapan pengetahuan akademis, juga kecakapan sosial, dan spritual, sehingga bisa membawa murid kearah perkembangan yang benar.

\section{Peran Guru dalam Pembelajaran.}

\section{a. Guru sebagai pendidik}

Pendidik adalah orang yang dengan sengaja mempengaruhi orang lain untuk mencapai tujuan pendidikan. Pendidik sebagaimana

${ }^{9}$ Kamus Besar Bahasa Indonesia, dalam http:/ / kbbi.web.id/guru.html diakses pada tanggal 10 juli 2018 pukul 20.51 Wita.

${ }^{10}$ Taman Firdaus, Pembelajaran Aktif: Aspek, Teori Dan Implementasi, (Yogyakarta: Elmatera, 2012), hal.95.

${ }^{11}$ Zainal Aqib, Profesonalisme Guru Dalam Pembelajaran, (Surabaya: Insan Cendekia, 2002), hal.96.

Jurnal Pelangi Jurnal pemikiran dan penelitian pendidikan Islam anak Usia Dini 
dikemukakan oleh Poerwadarminta dalam Tasrif adalah orang yang mendidik. Pengertian mengandung pandangan bahwa pendidik adalah orang yang melakukan kegiatan dalam bidang mendidik. ${ }^{12}$

Menurut Cooper guru adalah orang yang bertanggung jawab mengajarkan (mendakwahkan), menanamkan dan membantu orang lain untuk belajar dan untuk bertindak dengan jalan yang baru. ${ }^{13}$ Guru sebagai pendidik adaah mentransformasi ilmu, pengetahuan, komunikasi, dan teknologi dan seni serta nilai peserta didik baik dalam lingkungan sekolah maupun di lingkungan sosial.

\section{b. Guru sebagai pengajar}

Kata yang tepat untuk pekerjaan mengajar adalah to teach yang berarti mengajar sedanglan orangnya sering disebut dengan Teacher. Cooper mengatakan bahwa mengajar merupakan proses penanaman pengetahuan dan keterampilan serta membantu proses pengungkapan sejumlah potensi peserta didik. Guru sebagai pengajar merupakan suatu konsep dimana guru bertugas menyampaikan ilmu dan pengetahuan kepada peserta didik dalam suatu konteks waktu tertentu. Zakia Darajat menambahkan bahwa mengajar merupakan konsep transfer of knowledge, guru bertanggung jawab terhadpat proses pelaksanaan pembelajaran. ${ }^{14}$

\section{c. Guru sebagai teladan}

Guru adalah individu yang "digugu dan ditiru" yang berarti yang diikuti dan ditiru. Sifat dan perbuatan yang ditiru dan diikuti adalah karya (works) dan sikap (attitude) positif dan moral dari seorang guru. Konsep ini dalam pendidikan agama Islam sering disebut dengan istilah uswatun hasanah, sebuah contoh dan perangai positif tertentu yang dilakoni oleh individu. ${ }^{15}$ Rasulullah Saw mendeskripsikan keteladanan adalah cara efektif dalam pendidikan kepribadian siswa, terutama pada usia dini sampai remaja. Pada saat itu mereka mengalami fluktuasi kejiwaan yang memuncak. ${ }^{16}$

\footnotetext{
${ }^{12}$ Tasrif, Profesi Keguruan (Landasan Kerja Guru Profesional), (Yogyakarta: Kurnia Kalam Semesta, 2011), hal.119.

${ }^{13} \mathrm{Ibid}, \ldots . .$. hal.120.

${ }^{14}$ Ibid.,124

${ }^{15}$ Ibid., 125

${ }^{16}$ Ibid.,127
} 
Dalam konteks pembelajaran dan pendidikan, implementasi metode keteladanan menuntut personafikasi kepribadian guru yang positif. Begitu urgennya metode ini sehingga Al-Qur'an mengabadikan dan melukiskan pribadi Nabi Muhammad Saw dalam relasi dengan sahabat-sahabatnya dengan firmannya;

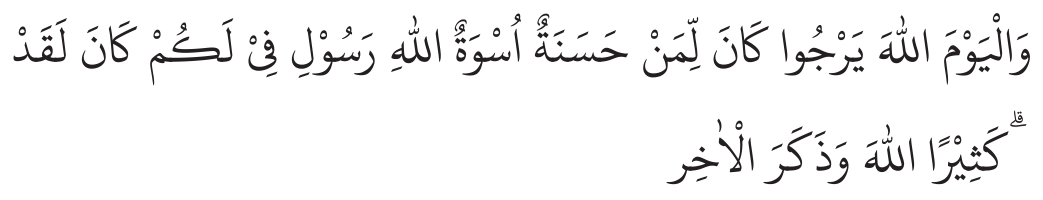

Artinya: Sungguh, telah ada pada (diri) Rasulullah itu suri teladan yang baik bagimu (yaitu) bagi orang yang mengharap (rahmat) Allah dan (kedatangan) hari Kiamat dan yang banyak mengingat Allah.» (Q.S. AlAhzab 33: Ayat 21). ${ }^{17}$

Jadi, pendidikan menuntut tindakan percontohan lebih banyak daripada pengajaran verbal, dapat dikatakan bahwa pendidikan dengan bahasa perbuatan untuk anak adalah lebih efektif daripada pendidikan dengan bahasa ucapan.

\section{d. Guru sebagai fasilitator}

Guru sebagai fasilitator berangkat dari paradigma pendidikan Paulo Freire dimana tugas guru sebagai fasilitator adalah to facilitate student for learning yaitu membantu peserta didik melakukan proses kegiatan pembelajaran dengan baik. Menfasilitasi berarti guru berada dalam suatu posisi sebagai membantu siswa dalam belajar, bukan memberikan doktrin dan ajaran tertentu apalagi dengan cara kekerasan, melainkan menciptakan suatu kondisi pembelajaran demokratis, tertertib, terbuka dan menyenangkan bagi peserta didik.

\section{e. Guru sebagai Motivator}

Tugas guru sebagai motivator adalah membangun sikap belajar dengan penuh semangat dan motivasi tinggi untuk mencapai tujuan pembelajaran, artinya guru sebagai motivator membangun kembali semangat belajar siswa yang telah "layu" dengan cara memberikan terapi dan perlakuan belajar pada peserta didik, terutama terapi mental dam psikologi bagi siswa yang mengalami masalah belajar.

${ }^{17}$ QS. Al-Ahzab 33: Ayat 21.

Jurnal Pelang̉i Jurnal pemikiran dan penelitian pendidikan Islam anak Usia Dini 


\section{f. Guru sebagai evaluator}

Dalam hal memahami prestasi belajar siswa, perlu dilakukan suatu evaluasi oleh seorang evaluator (guru) tentang proses dan output. Tugas guru sebagai evaluator adalah mengadakan suatu pembelajaran dalam suatu jenis periode waktu tertentu. Melakukan suatu evaluasi merupakan hal terpenting dalam tugas guru, hal tersebut bertujuan untuk mengetahui capaian prestasi belajar siswa selama kegiatan pembelajaran. ${ }^{18}$

\section{g. Guru sebagai Pembimbing dan Konselor}

Guru sebagai pembimbing memberikan tekanan kepada tugas, memberikan bantuan kepada siswa dalam memecahkan masalah yang dihadapinya. Dalam hal ini, berkaitan erat dengan tugas sebagai pendidik, yaitu tidak hanya menyampaikan sejumlah pengetahuan atau keterampilan kepada peserta didik tetapi juga menyangkut pengembangan kepribadian dan pembentukan nilainilai kepada siswa. Karena guru mempunyai banyak kesempatan untuk mempelajari peserta didik, mengawasi segala tingkah laku peserta didik, mengawasi segala masalahnya dan sebagainya. ${ }^{19}$

Jadi tugas guru dalam pembelajaran ada 8 yakni guru sebagai pendidik, pengajar, teladan, fasilitator, motivator, evaluator, administrator dan guru sebagai pembimbing dan konselor.

\section{MAJA LABO DAHU SEBAGAI BAGIAN DARI KEBUDAYAAN BIMA}

Menurut Peter Cary, Kesultanan Bima merupakan Kesultanan di Indonesia bagian Timur yang tersohor karena ketaatan pada agama Islam. selain itu mereka juga diakui sebagai masyarakat yang taat pada sistem budayanya (adatnya), dan sistem budaya yang mereka pegang teguh harus sesuai dengan norma agama. ${ }^{20}$

Kelebihan sistem budaya Mbojo diakui banyak pakar antara lain Mr. Van Valenhoven, seorang hukum adat dari Belanda, bahwa sistem/ struktur pengaturan pelaksaan adat kesultanan Bima adalah sangat

\footnotetext{
${ }^{18}$ Tasrif, Profesi Keguruan............, 135

19Ibid,......hal.137.

${ }^{20}$ Mutawali, Islam Moderen............hal.20.
} 
sistematis dan sangat kuat. Pola yang dipakai adalah pola pengaturan Bugis Makassar, tetapi dalam bentuk yang agak berlainan dan lebih demokratis. ${ }^{21}$

Seruan Allah dan anjuran Rasul untuk melaksanakan adat yang baik dipenuhi oleh masyarakat masa lalu. Agar perintah Allah dan Rasul diikuti dan dipatuhi oleh masyarakat, sultan dan ulama membuat suatu gagasan yang akan dijadikan sebagai falsafah hidup dan diberi nama Maja Labo Dahu (malu dan takut), yang bermakna siapa saja yang melanggar perintah Tuhan dan Rasulnya, dia harus malu dan takut pada Tuhan, malu pada manusia lainnya, dan malu pada dirinya sendiri. Dan apabila melanggar falsafah Maja Labo Dahu, berarti melanggar perintah agama dan adatnya. ${ }^{22}$

Maja labo dahu merupakan simbol bagi upaya kalangan agamawan dan adat Bima dalam menegakkan al-amar bi-al ma'ruf wan-nahyu anil munkar di tengah tengah masyarakat lokal. Dalam banyak uraian dan kajian mengenai maja labo dahu selalu menegakkan hal-hal yang bersifat Islam seperti rasa takut dan malu kepada Tuhan apabila tidak melakukan perbuatan yang diperintahkan, atau penyesalan apabila melakukan perbuatan buruk, jahat, dan menyimpang dari nilai-nilai Islam.

Karena itu, maja labo dahu berkorelasi langsung dengan makna keimanan, ketaqwaan, dan keikhlasan dalam menjalankan segala perintah Tuhan, berbuat baik sesama manusia serta perasaan malu dan takut pada diri sendiri apabila menyimpang dari nilai-nilai agama dan adat. ${ }^{23}$

Dalam hadist juga disebutkan tentang malu adalah sebagian dari iman.

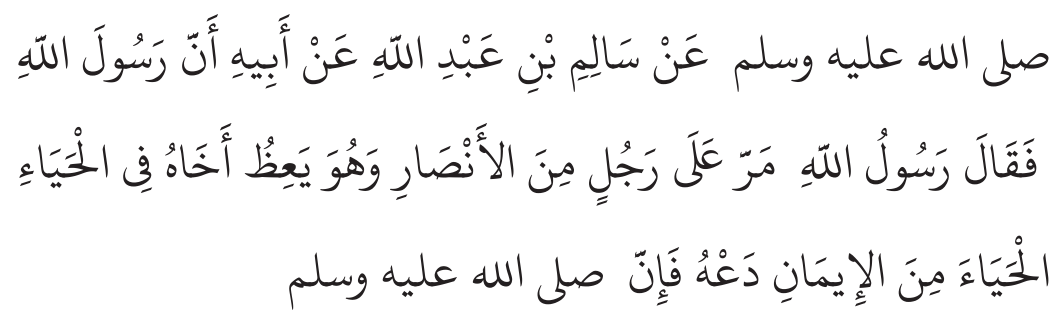

${ }^{21}$ Ibid,.......hal.21.

${ }^{22} \mathrm{Ibid}, \ldots . . . \mathrm{hal} .22$.

${ }^{23}$ Syarifuddin Jurdi, Islam Masyarakat Madani Dan Demokrasi Di Bima: Membangun Demokrasi Kultural Berbasis Religius, (Makassar : Alauddin university press, 2011), hal.217.

Jurnal Pelang̉i Jurnal pemikiran dan penelitian pendidikan Islam anak Usia Dini 
Artinya: Dari Salim bin Abdullah, dari ayahnya, ia berkata, «Rasulullah SAW lewat di hadapan seorang Ansar yang sedang mencela saudaranya karena saudaranya pemalu. Maka Rasulullah SAW bersabda, <Biarkan dia! Sesungguhnya malu itu sebagian dari iman. ${ }^{24}$

Maka dalam hadits ini Rasulullah SAW mengingatkan bahwa yang benar justru adalah tidak menghilangkan rasa malu dalam diri saudaranya. Biarkan saja seseorang memiliki sifat malu. Ia adalah akhlak yang disunnahkan. Malu adalah sebagian dari iman.

Didalam kitab "BO" kitab kesultanan Bima, maja labo dahu berarti malu untuk berbuat hal-hal yang di luar batas norma susila dan takut untuk melakukan hal-hal yang dilarang oleh agama. Secara sederhana falsafah ini mengisyaratkan pesan untuk malu kepada manusia jika melakukan tindakan yang tercela dan takut terhadap balasan dari Allah atas perbuatannya. Petuah ini menunjukkan eksistensi dou Mbojo yang menjunjung tinggi rasa kebersamaan secara insan (hamblum minnas) dan sinergitas dengan ketundukan kepada sang al-Khalik (hablum minallah). Istilah maja (malu) Maja labo dahu merupakan suatu nilai yang dijadikan sebuah kearifan lokal bagi masyarakat Bima. Juga sebagai norma adat yang berlaku dalam tataran kehidupan masyarakat Bima. Secara konseptual dalam bahasa Indonesia kata maja labo dahu memiliki makna yang sama dengan kata sirri napacce, sama-sama memiliki makna malu dan takut. ${ }^{25}$

Didalam sasanti Maja Labo Dahu ada dua kata kunci, yaitu "maja" dan "dahu". Secara harafiah kedua kata tersebut masing-masing bermakna malu dan takut/taqwa. Ditinjau dari sudut falsafat kedua kata tersebut mengandung pengertian yang luas dan dalam. Aspek pertama dari inti ajaran etika tersebut mengandung "budaya malu” yang tertanam dalam kalbu setiap insan "Dou Mbojo" menjadikan seseorang mampu mengendalikan diri untuk tidak berbuat sesuatu yang tidak baik (terlarang), yang dipandang tidak patut dan tidak sesuai dengan etika kehidupan manusia yangn bermoral dan beradab. Rasa malu yang terpancar dari dalam kalbu seseorang akan mengendalikan nafsunya

\footnotetext{
${ }^{24}$ Achmad Sunarto \& Dkk, Terjemahan Shahih Bukhari (Semarang: Asy-Sifa, 1992), hal.27.

${ }^{25}$ Didi Haryono, "Makna falsafah Maja labo dahu dalam kultur masyarakat Bima" dalam www.mbojolokpedia.com diakses pada tanggal 23 Oktober 2018 pukul 8.32
} 
sehingga tidak melanggar norma agama, norma susila dan norma hukum.

Aspek kedua mengandung pengertian takut, takut kepada Allah sama dengan nilai taqwa. Malu dan takut/taqwa saling melengkapi sehingga ajaran etika tersebut mampu membentuk kepribadian yang di dalamnya tertanam nilai moral yang luhur sebagai wahana pengendalian diri yang ampuh. Oleh sebab itu ajaran etika tersebut haruslah benar-benar diamalkan dalam kehidupan bermasyarakat, berbangsa dan bernegara. ${ }^{26}$

Maja Labo Dahu mengandung seperangkat nilai yang oleh masyarakat pendukungnya dijadikan sebagai sistem yang harus dijabarkan dalam semua unsur budaya yang terdiri dari lima unsur. Pertama unsur Bahasa, Bahasa sebagai alat konseptualisasi budaya dan seni harus dikembangkan berdasarkan system yang berlaku. Menurut masyarakat Bima, bahasa merupakan gambaran jati diri masyarakat, karena itu penggunaannya harus berpedoman pada nilai Maja Labo Dahu. ${ }^{27}$

Pemakaian bahasa dalam kehidupan sehari-hari harus berpedoman kepada norma bahasa yang terkandung dalam ungkapan " ma ne'e salama morimu, sandakapu nggahi ro eli ro ruku ro rawi mubalig, ro lampa ro laomu" yang berarti "jika ingin selamat dalam hidupmu, peliharalah tutur katamu, tingkah lakumu, perjalanan dan kepergianmu". Pernyataan ini bukan hanya pedoman dalam bahasa tetapi juga merupakan pedoman dalam melakukan dan mengembangkan unsur lain dari kebudayaan.

Kedua Sistem teknologi. Untuk teknologi yang dibahas dalam tulisan ini, hanya terbatas pada tiga hal yaitu unsur pakaian, perumahan, dan senjata. Karena ketiga unsur tersebut paling banyak hubungannya dengan nilai Maja Labo Dahu. Pakaian dalam bahasa Bima dikenal dengan istilah "Kani ro Lombo", merupakan salah satu kebutuhan yang mendasar bagi masyarakat. Fungsi utamanya ialah untuk menutup aurat, memelihara kesehatan, sebagai pembeda status serta menambah kewibawaan. Perumahan yang oleh masyarakat Bima "Uma ro Salaja" merupakan salah satu kebudayaan yang mendasar.

Setia orang yang sudah berumah tangga harus memiliki rumah, kalau tidak, maka kepala rumah tangga (suami) akan merasa Maja

\footnotetext{
${ }^{26}$ Sahidu, Djamaluddin, Kampung Orang Bima, (Mataram : Studio 15, 2008), hal.54.

${ }^{27}$ Mariati, "Maja Labo Dahu Dalam Dinamika Kehidupan Masyarakat Bima", ("Skripsi", Universitas Islam Negeri Makassar, Makassar, 2013), hal.5.
}

Jurnal Pelang̉i Jurnal pemikiran dan penelitian pendidikan Islam anak Usia Dini 
(Takut). Daha taho "daha pusaka" (senjata pusaka) harus dimiliki oleh setiap rumah tangga, sebagai lambang keperkasaan keluarga. Senjata pusaka harus dijaga dan dipelihara, tidak boleh dipergunakan untuk melakukan hal yang onar, tetapi harus digunakan untuk membela keadilan dan kebenaran. ${ }^{28}$

Ketiga, Mata Pencaharian. Dalam bahasa Bima istilah mata pencaharian disebut "Ngupa ro Dei di Ru'u Mori ro Woko. (Mencari nafkah untuk hidup dan kehidupan, dalam pengertian mencari nafkah untuk kesejahteraan hidup). Masyarakat Bima mengenal tiga sistem mata pencaharian utama yang terdiri dari pertanian, peternakan dan perniagaan.

Keempat Sistem Kemasyarakatan. Sistem kekerabatan orang Bima berdasarkan sampai seberapa jauh peranan nilai "s" sebagai pusat hidup dan kehidupan, dalam sistem kemasyarakatan yang meliputi system kekerabatan, politik, pemerintahan, hukum dan system perkawinan. Yang kelima Ilmu pengetahuan dan kesenian. Sejak lama masyarakat Bima menyadari pentingnya sumber daya manusia bagi kelangsungan hidup masyarakat. Peningkatan sumber daya manusia dilaksanakan melalui ilmu pengetahuan dan kesenian. ${ }^{29}$ Kelima unsur tersebut yang membuktikan bahwa maja labo dahu merupakan bagian dari unsur pembentuk kebudayaan Bima yang tidak bisa dilepaskan dari masyarakat Bima itu sendiri.

Maja labo dahu memiliki peranan yang sangat besar dalam kehidupan etnis Bima. Bagi seorang individu dalam kehidupan bermasyarakat, nilai ini menjadi alat kontrol yang mengawasi setiap perilaku dalam berbagai bidang kehidupan. Maja labo dahu dalam realitas kehidupan masyarakat merupakan satu norma moral yang lahir dan sekaligus mampu mengatasi watak masyarakat etnis Bima yang cenderung keras.

Agama mengajarkan tentang moral, nilai etika, pentingnya melakukan perbuatan baik tidak diperbolehkan untuk melakukan suatu perbuatan yang buruk. Dalam agama Islam banyak sekali ayat-ayat dalam al-Quran dan hadis-hadis nabi yang berbicara tentang karakter atau dalam agama disebut dengan akhlak. ${ }^{30}$

\footnotetext{
${ }^{28} \mathrm{Ibid}, \ldots . . .$. hal.6.

${ }^{29} \mathrm{Ibid}, \ldots . . . . \mathrm{hal} .7$.

${ }^{30}$ Muhammad Yaumi, Pilar-Pilar Pendidikan Karakter, ( Makassar: Alauddin University Press,
} 
Dapat dipahami bahwa akhlak sebagai dasar merupakan refleksi yang dimiliki seseorang. Jika tabiat tersebut baik maka dengan sendirinya seseorang dikatakan memiliki akhlak yang baik. Sebaliknya jika seseorang mempunyai tabiat yangjelek, maka ia dikatakan mempuyai akhlak yangjelek pula. Akhlak adalah dasar utama dalam pembentukan pibadi/karakter manusia yang seutuhnya. pendidikan yang mengarah pada terbentuknya pribadi berakhlak merupakan hal pertama yang harus dilakukan, sebab akan melandasi kestabilan kepribadian dan keimanan manusia secara keseluruhan. ${ }^{31}$

Nilai-nilai menurut pandangan islam yang harus ditanamkan pada Anak Usia Dini adalah:

1. Nilai keimanan

Menurut Rois Mahfud nilai keimanan merupakan landasan pokok sebagai pengembangan fitrah bagi manusia yang mempunyai sifat dan kecenderungan untuk mengakui dan mempercayai adanya Tuhan. ${ }^{32}$

2. Nilai Ibadah

Penanaman nilai ibadah secara sederhana harus dilakukan semenjak dini. Artinya penanaman ibadah ini tidak bersifat membebani jiwa anak namun sebatas latihan dalam menjalani masa persiapan guna menyambut masa pembebanan kewajiban (taqlif) ketika anak kelak telah memasuki usia baliqh.

3. Nilai Akhlak

Akhlak adalah sesuatu yang telah tercipta atau terbentuk melalui sebuah proses. ${ }^{33}$ Sedangkan menurut Mansur dalam bahasa Yunani, untuk pengertian akhlak ini dipakai kata ethos, ethiko yang kemudian menjadi etika. Manusia akan menjadi sempurna jika mempunyai akhlak terpuji. Nilai akhlak menurut Tarazi apabila anak dibesarkan dengan bimbingan akhlak yang mulia dari orang tua dan lingkungan yang kondusif maka dia akan memiliki banyak figur untuk diteladani dan membantu dalam pembentukan pribadi yang islam pada diri anak. Ketiga nilai diatas juga merupakan nilai-nilai yang termasuk di dalam falsafah maja labo dahu yang pada ungkapan taho (kebaikan) dan

2012), hal.49.

${ }^{31}$ B. Marjani Alwi, Pendidikan Karakter: Solusi Bijak Menyikapi Perilaku Menyimpang Anak (Makassar:Alauddin University Press, 2014) ,hal.109.

${ }^{32}$ Sapendi, Internalisasi Nilai-Nilai Moral Agama Pada Anak Usia Dini, Jurnal Dosen, Vol.9, (2015). hal.19.

${ }^{33}$ Sapendi, "Internalisasi Nilaihal.20.

Jurnal Pelang̉i Jurnal pemikiran dan penelitian pendidikan Islam anak Usia Dini 
iha (keburukan) pada ungkapan tersebut adalah berpedoman pada nilainilai luhur yang terkandung dalam iman dan takwa. Pada dasarnya fungsi dan peranan Maja Labo Dahu adalah untuk menumbuhkan serta meningkatkan keimanan dan ketakwaan masyarakat, agar dalam melaksanakan tugasnya sebagai khalifah Allah selalu mendekatkan diri kepada-Nya melalui kegiatan 'Ubudiah serta $M u^{\prime}$ amalah. ${ }^{34}$

Maka melalui maja labo dahu manusia akan berupaya untuk menegakkan amar ma'ruf nahi munkar sehingga manusia akan dapat berperan sebagai khalifatul di muka bumi dan sebagai pengabdi Allah. Kalau upaya tersebut dapat dilaksanakan, maka cita-cita menuju sana mori di dunia akherat (kebahagian di dunia dan akhirat) dan berlakunya sistem nilai budaya seperti yang terkandung dalam adat Mbojo dapat diwujudkan menjadi kenyataan konkret, baik dalam wujud tingkah laku maupun kebudayan fisik. ${ }^{35}$

Dalam melaksanakan tugasnya, selalu memegang teguh nilai-nilai luhur Maja Labo Dahu sebagai berikut:

1) Renta ba rera kepoda ade ro karawi ba weki, yang artinya yang diikrarkan oleh lidah harus sesuai dengan suara hati nurani dan pula diamalkan. Dalam konteks ini, nilai kecerdasan spiritual sangat membantu seseorang dalam mengikrarkan dan mengamalkan sesuatu. Dalam konsepsi kecerdasan spiritual, bisikan hati merupakan pancaran nur Ilahi dari Khalik kepada makhluk-Nya yang selalu menjaga amal ibadahnya. ${ }^{36}$ Nilai pendidikan karakter yang terkandung dalam petuah ini adalah nilai keimanan, ibadah, dan akhlak serta manusia haruslah bersikap tanggungjawab atas segala perbuatan yang dilakukan dan diucapkan.

2) Mbolo ra dampa atau mufaka ro dampa, yang berarti menjunjung tinggi azas kekeluargaan dan musyawarah. Dalam hal ini anak diajarkan cinta damai, yakni tidak peduli masalah apa yang dihadapi harus diselsesaikan secara bersama-sama atau bekerja sama.

3) Karawikaboju, artinya gotong royong. Nilai pendidikan karakter yang ada dalam petuah ini adalah bekerja sama dan saling membantu.

4) Nggahi rawi pahu, yang berarti bahwa apa yang diikrarkan dalam hati yang telah diprogramkan harus diwujudkan menjadi kenyataan.

\footnotetext{
${ }^{34} \mathrm{Ibid}, \ldots . . .$. hal.22.

${ }^{35}$ Mutawali, Islam di............hal.22.

${ }^{36} \mathrm{Ibid}, \ldots . . . . \mathrm{hal} .22$.
} 
Dalam nilai luhur ini terkandung nilai pendidikan karakter yang sama dengan nilai kejujuran dan disiplin.

5) Su'u sawa'u sia sawale, yang artinya bagaiamanapun beratnya tugas yang diemban, harus dijalankan dengan sabar dan tabah, pantang untuk lari dari tanggungjawab. ${ }^{37}$ Dalam nilai luhur ini terkandung nilai karakter yang harus ditanamkan kepada anak yaitu nilai sabar, ikhlas dan bertanggungjawab.

6) Tahompara nahu sura dou labo dana, yang bermakna semua hasil pembangunan yang telah dicapai melalui perjuangan seluruh rakyat harus dinikmati secara adil, sesuai besar kecilnya tanggungjawab. Dalam nilai luhur ini dapat kita ketahui bahwa ada nilai karakter yaitu nilai keadilan.

7) Tahompara nahu sura dou ma rimpa. Nilai luhur ini ditujukan kepada kelompok yang memiliki nilai lebih baik dari segi harta maupun kekuasaan, agar selalu memikirkan kepentingan orang lain dan harus memiliki kepedulian yang tinggi. ${ }^{38}$ Artinya nilai luhur ini memiliki, maksudnya tidak mementingkan diri sendiri melainkan memikirkan kepentingan semua orang dan berbagi.

Dari penjelasan diatas dapat peneliti simpulkan bahwa nilai-nilai yang terkandung dalam falsafah maja labo dahu yang harus ditanamkan kepada anak usia dini adalah nilai keimanan, ibadah dan ketaqwaan kepada Allah (spiritual), saling membantu dan bekerja sama dengan orang lain, nilai keadilan, kejujuran, kedisiplinan, bertanggjawab, sabar, serta ikhlas berbagi.

\section{METODELOGI PENELITIAN}

Penelitian ini menggunakan jenis penelitian kualitatif. Penelitian kualititatif mempelajari situasi nyata dengan mengadakan kontak langsung dan dekat dengan orang-orang, situasi-situasi serta fenomenafenomena yang dipelajari, pengalaman pribadi peneliti untuk mencari penemuan-penemuan dalam konteks sosial, historis dan temporal. Penelitian kualitatif menghasilkan data deskriptif berupa kata-kata tertulis atau lisan dari orang-orang dan perwujudan perilaku yang dapat

\footnotetext{
${ }^{37}$ Ibid.,23
}

${ }^{38} \mathrm{Ibid} ., 23$

Jurnal Pelangi Jurnal pemikiran dan penelitian pendidikan Islam anak Usia Dini 
diamati. ${ }^{39}$ Tujuan menggunakan pendekatan deskriptif pada penelitian ini untuk menjelaskan “Upaya Guru Dalam Menginternalisasikan NilaiNilai Sikap Maja Labo Dahu pada anak kelas B di TK Negeri Pembina 03 Rasana'e Barat Kota Bima". ${ }^{40}$

\section{SUMBER DATA DAN TEHNIK PENGUMPULAN DATA SUMBER DATA}

a. Data primer adalah sumber data yang langsung memberikan data kepada pengumpul data. Di sini sumber data primer yang di ambil oleh peneliti yaitu guru yang mengajar langsung di kelas yang menjadi fokus masalah penelitian.

b. Data sekunder merupakan sumber data yang tidak langsung memberikan data kepada kepada pengumpul data. ${ }^{41}$ Peneliti menjadikan dokumen perkembangan anak sebagai data pelengkap, dan observasi di lapangan langsung.

Adapun sumber data yang dipergunakan dalam penelitian ini adalah sumber data primer dan sekaligus sumber data sekunder. Data primer yaitu data yang diperoleh langsung dari responden berdasarkan wawancara yang dilakukan peneliti. Sementara data sekunder yaitu data yang diperoleh dari dokumen-dokumen, arsip-arsip dan lain-lain yang berkaitan dengan data yang dibutuhkan pada penelitian ini.

\section{Teknik Pengumpulan Data}

\section{a. Observasi}

Nasution mengatakan bahwa observasi adalah dasar semua ilmu pengetahuan. Para ilmuwan hanya dapat bekerja berdasarkan data, yaitu fakta mengenai dunia kenyataan yang diperoleh melalui observasi. ${ }^{42}$

Marshal menyatakan bahwa melalui observasi peneliti belajar tentang perilaku, dan makna dari perilaku tersebut. Dalam penelitian ini, peneliti melakukan jenis observasi partisipatif dimana peneliti terlibat dengan kegiatan sehari-hari orang yang sedang diamati atau yang digunakan

\footnotetext{
${ }^{39}$ Margono, Metodologi Penelitian,(Jakarta:Penerbit Rineka Cipta, 2003), hal.36.

${ }^{40}$ Sugiyono. Metode Penelitian Kuantitatif, Kualitatif dan RED, (Alfabeta: Bandung, 2013), hal.245.

${ }^{41}$ Ibid, .......hal.225.

${ }^{42}$ Sugiyono. Metode Penelitian. , 226
} 
sebagai sumber data penelitian. Dalam observasi partispatif, peneliti mengamati apa yang dikerjakan orang, mendengarkan apa yang mereka ucapkan, dan berpasrtisipasi dalam aktivitas mereka. ${ }^{43}$

Observasi partisipatif adalah untuk mengetahui keadaan lokasi penelitian, seperti; pelaksanaan $\mathrm{KBM}$, dan kegiatan bermain di dalam (bermain: balok-balok, bongkar pasang, menggambar, dan lainnya) maupun di luar kelas (perosotan, jungkat jungkit, ayunan, dan lainnya) pada saat istirahat. Dari situlah peneliti dapat mengamati secara langsung apakah anak mengamalkan nilai maja labo dahu yang diajarkan oleh guru atau tidak.

\section{b. Wawancara}

Wawancara adalah suatu percakapan, tanya jawab lisan antara dua orang atau lebih yang duduk berhadapan secara fisik dan diarahkan pada suatu masalah tertentu sesuai dengan perjanjian sebelum. ${ }^{44}$

Jadi dengan wawancara, maka peneliti akan mengetahui hal-hal yang lebih mendalam tentang partisipan dalam menginterprestasikan situasi dan fenomena yang terjadi, dimana hal ini tidak bisa ditemukan melalui observasi. ${ }^{45}$ Di sini peneliti melakukan wawancara langsung dengan guru yang mengajar dalam kelas B1 untuk mendapatkan data yang dibutuhkan dalam penelitian ini.

\section{c. Dokumentasi}

Dokumentasi yaitu mencari mengenai hal-hal atau variabel yang berupa catatan, transkrip, buku, surat kabar, majalah, agenda dan lain sebagainya ${ }^{46}$ Disini peneliti mencari data tentang perkembangan anak sebagai data penunjang dalam menyusun penelitian ini.

\section{A. Instrumen Penelitian}

Intrumen penelitian adalah alat atau fasilitas yang digunakan untuk mempermudah penelitian dalam pengumpulan data, sehingga data yang diperoleh jelas, sistematis, lebih cermat, lengkap serta prosesnya

${ }^{43}$ Ibid...,227

${ }^{44}$ Ahmad Usman, Mari Belajar Meneilti, (Yogyakarta:Genta Press, 2008), 286.

${ }^{45}$ Sugiyono. Metode Penelitian...... 232

${ }^{46}$ Suharsimi Arikunto, Prosedur Penelitian Suatu Pendekatan Praktek, Edisi Revisi V (Jakarta:Rineka Cipta, 2006), 109

Jurnal Pelangi Jurnal pemikiran dan penelitian pendidikan Islam anak Usia Dini 
lebih mudah. Instrument penelitian merupakan alat atau fasilitas yang digunakan oleh peneliti dalam sebuah penelitian dengan tujuan agar data yang diperoleh lebih valid dan akurat. ${ }^{47}$

Instrumen dalam penelitian ini adalah sebagai berikut:
a. Lembar Observasi
b. Wawancara
c. Dokumentasi

\section{B. Teknik Analisis Data}

Setelah data tersebut terkumpulkan dengan lengkap dari laporan, tahapan berikutnya adalah tahapan analisis data untuk dapat diambil kesimpulan sesuai dengan jenisnya. Analisis data adalah proses mencari dan menyusun secara sistematis data yang diperoleh dari hasil wawancara, catatan lapangan, dan bahan-bahan lain, sehingga dapat mudah dipahami, dan temuannya dapat diinformasikan kepada orang lain.

Analisis data dilakukan dengan mengorganisasikan data, menjabarkannya kedalam unit-unit, melakukan sintesa, menyusun kedalam pola, memilih mana yang penting dan yang akan dipelajari, dan membuat kesimpulan yang dapat dicerikan kepada orang lain. ${ }^{48}$

Dalam menganalisa data yang bersifat kualitatif ini, maka menggunakan pola pikir deskriptif analisis induktif adalah berpikir yang berangkat dari faktor-faktor yang khusus, peristiwa yang kongkrit, kemudian dari faktor dan peristiwa yang kongkrit itu ditariklah generalisasi yang mempuanyai sifat umum. ${ }^{49}$

Bersifat induktif yaitu suatu analisis yang berdasarkan data yang diperoleh. Hipotesis yang dirumuskan berdasarkan data tersebut, selanjutnya dicarikan data lagi secara berulang-ulang sehingga selanjutnya dapat disimpulkan apakah hipotesis tersebut diterima atau ditolak berdasarkan data yang tekumpul. ${ }^{50}$

Dalam menganalisa data yang di dapat selama wawancara, peneliti menggunakan model Miles dan Huberman. Analisa data kulitatitif

${ }^{47}$ Ma'rifah, Persepsi Siswa Tentang Kepribaian Guru dengan Motivasi belajar PAI Di SMAN 5 Kota Bima, Skripsi, (STAIM Bima: 2012). 49.

${ }^{48}$ Sugiyono. Metode Penelitian............,244

${ }^{49} \mathrm{hmad}$ Usman. Mari BelajarMeneliti..............242

${ }^{50}$ Sugiyono. Metode penelitian , 245 
dilakukan pada saat pengumpulan data berlangsung dan setelah selesai pengumpulan data ${ }^{51}$. Kegiatan analisis dan pengumpulan data dilakukan interaktif dan merupakan siklus yang berulang-ulang, berlanjut secara terus-menerus dan saling menyusun sampai kegiatan akhir dalam penelitian siap dikerjakan. Model interaktif oleh Huberman dan Miles adalah sebagai berikut :

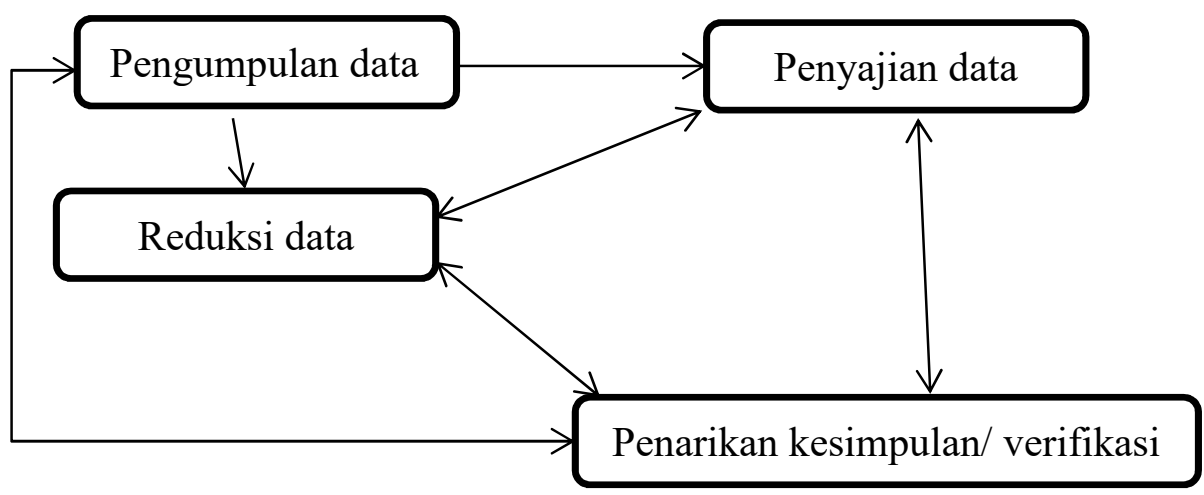

Gambar 1. Model interaktif Huberman dan Miles

\section{1) Reduksi data (Reduction data)}

Data yang diperoleh dari lapangan jumlahnya cukup banyak, untuk itu maka perlu dicatat secara teliti dan rinci. Mereduksi data berarti merangkum, memilih hal-hal yang pokok, memfokuskan pada hal-hal yang penting, dicari tema dan polanya. ${ }^{52}$

Dalam hal ini peneliti lebih memerhatikan pelaksanaan pembelajaran dalam Menginternalisasikan Nilai-Nilai sikap maja labo dahu pada anak di kelas B1.

\section{2) Penyajian data (display data)}

Dalam penelitian kualitatif penyajian data bisa dilakukan dalam bentuk uraian singkat, bagan, hubungan antar kategori, dan sejenisnya. Miles dan Huberman menyatakan penyajian data dalam penelitian kualitatif adalah dengan teks yang bersifat naratif ${ }^{53}$.

\footnotetext{
${ }^{51}$ Ibid...,246

${ }^{52}$ Ibid.., 247

${ }^{53}$ Ibid..,249
}

Jurnal Pelangi Jurnal pemikiran dan penelitian pendidikan Islam anak Usia Dini 
Dalam hal ini peneliti menyajikan data dalam bentuk teks yang bersifat naratif dan diperkuat oleh catatan wawancara, observasi dan dokumentasi.

\section{3) Penarikan kesimpulan atau verifikasi}

Langkah terakhir dalam analisis data menurut Miles dan Huberman adalah penarikan kesimpulan dan verifikasi. Kesimpulan dilakukan diawal masih bersifat sementara dan akan dikuatkan dengan bukti-bukti yang mendukung dari hasil observasi, wawancara, dan dokumentasi. Peneliti melakukan verifikasi dari hasil observasi, wawancara dan dokumentasi untuk mempertahankan dan memberikan jaminan keabsahan data.

\section{Pengujian Kredibilitas Data}

Dalam penelitian ini ada empat kriteria pengujian kredibilitas data yang dipergunakan yaitu:

\section{Perpanjangan pengamatan}

Dengan perpanjangan pengamatan berarti peneliti kembali ke lapangan, melakukan pengamatan, wawancara lagi dengan sumber data yang pernah ditemui maupun yang baru. Dengan perpanjangan pengatamatan ini berarti hubungan peneliti dengan narasumber akan semakin terbentuk rapport, semakin akrap (tidak ada jarak lagi), semakin terbuka, saling mempercayai, sehingga tidak ada informasi yang di sembunyikan lagi. ${ }^{54}$ Bila telah terbentuk rapport, maka telah terjadi kewajaran dalam penelitian, dimana kehadiran penelitian tidak lagi mengganggu perilaku yang dipelajari.

\section{Cross Check}

Cross Check adalah kegiatan yang dilakukan oleh peneliti untuk melihat kebenaran terhadap data yang telah dikumpulkan dari hasil observasi, wawancara dan dokumentasi mengenai analisis latar belakang upaya guru dalam Menginternalisasikan Nilai-Nilai Sikap maja labo dahu pada anak Kelas B di Tk Negeri Pembina 03 Rasana'e Barat Kota Bima. Kegiatan ini dilakukan oleh peneliti agar tidak terjadi kesalahan terhadap data yang telah dikumpulkan oleh peneliti di lapangan.

\footnotetext{
${ }^{54}$ Sugiyono, Memahami Penelitian Kualitatif (Bandung : CV. ALFABETA, 2012), 122.
} 


\section{Triangulasi}

Triangulasi adalah proses mencari kebenaran data dari berbagai sumber dengan berbagai cara, dan berbagai waktu. Triangulasi dapat juga dilakukan dengan cara mengecek hasil penelitian. ${ }^{55}$ Dari kesimpulan di atas dapat dikatakan bahwa triangulasi adalah proses mencari kebenaran analisis latar belakang upaya guru dalam Menginternalisasikan NilaiNilai Sikap maja labo dahu pada anak kelas B di TK Negeri Pembina 03 Rasana'e Barat Kota Bima.

\section{Member check}

Member check adalah proses pengecekan data yang diperoleh peneliti kepada pemberi data. ${ }^{56}$ Kegiatan ini dilakukan oleh peneliti agar data yang dikum

\section{HASIL PENELITIAN}

\section{Upaya Guru Dalam Pengenalan Membaca Permulaan Anak Usia Dini (AUD) dengan Menggunakan Media Gambar Binatang Pada Kelompok B di TK Ma'aruf Desa Lanci Jaya Kab. Dompu}

Pembelajaran pendidikan TK bertujuan membantu meletakkan dasar kearah perkembangan sikap pengetahuan, keterampilan, daya cipta dan menyiapkan anak untuk memasuki pendidikan dasar dengan mengembangkan nilai-nilai agama (moral), fisik motorik, kognitif, bahasa, sosial emosi, dan seni. Stimulasi yang diberikan oleh guru merupakan hal yang sangat penting dalam pengenalan membaca permulaan anak usia dini. Dalam pengenalan membaca permulaan, dibutuhkan stimulasi. Stimulasi tersebut sangat membantu anak usia dini dalam pengenalan membaca.

Hasil wawancara dengan Bapak Ma'aruf, menyatakan bahwa upaya guru dalam pengenalan membaca anak usia dini di TK Ma'aruf dilakukan dengan menggunakan perminan gambar binatang;

"Guru sebagai pengajar biasanya dirumah akan memikirkan tema apa yang cocok untuk diterapakan pada saat proses belajar mengajar. Upaya yang dilakukan oleh guru adalah dengan menggunakan media

\footnotetext{
${ }^{55} \mathrm{Ibid}, 125$.
}

${ }^{56} \mathrm{Ibid}, 129$.

Jurnal Pelang̉ Jurnal pemikiran dan penelitian pendidikan Islam anak Usia Dini 
gambar binatang. Hal yang utama dilakukan adalah menentukan tema pembelajaran dan memilih gambar binatang yang sesuai dengan kebutuhan belajar anak usia dini. Di TK Ma;aruf pengenalan membaca permulaan dilakukan dengan menggunakan gambar media binatang, seperti gambar kuda, kambing, sapi, kerbau, dan kucing" ${ }^{57}$

Penggunaan media gambar binatang sangat membantu proses pengenalan membaca anak usia dini di TK Ma'aruf sehingga penggunaan media gambar binatang tersebut tetap digunakan dalam proses pembelajaran dari tahu ke tahun.

Sedangkan menurut Ibu Erma, S.Pd menyatakan bahwa upaya guru dalam pengenalan membaca permulaan anak usia dini di TK Ma'aruf adalah dilakukan dengan menggunakan media gambar binatang dan metode yang lain yang digunakan adalah menggunakan poster yang bertuliskan huruf abjad (A, B, C dan seterusnya). Berikut hasil wawancaranya"

“Upaya guru dalam pengenalan membaca permulaan anak usia dini di TK Ma'ruf dilakukan dengan menggunakan media gambar binatang, seperti media gambar binatang kuda, sapi, kerbau, harimau, laba-laba, kucing, dan singa. Dalam pengenalan membaca permulaan tersebut, guru menyediakan terlebih dahulu gambar binatang dirumah dan di print lalu waktu di sekolah ditempelkan di papan tulis, kemudian guru menanyakan ke siswa-siswi tentang gambar tersebut serta dibaca satu persatu dan siswa mengikutinya". ${ }^{58}$

Gambar sebagai media pendidikan dapat membuat anak untuk melatih dan mempertajam imajinasi anak, maka akan semakin berkembang sudut pandang anak dalam membahasakan gambar. Gambar seri adalah gambar yang urutanya secara seri yang bisa disesuaikan atau diurutkan sesuai dengan urutan jalan ceritanya. Seperti tergambar dalam ungkapan Syamsah, S.Pd, dibawah ini;

"Adapun istrumen yang digunakan oleh guru dalam meningkatkan kemampuan membaca permulaan adalah menggunakan gambar. Setelah siswa dapat membaca tulisan dibawah gambar, sedikit demi sedikit gambar dikurangi sehingga ahirnya mereka dapat membaca tanpa dibantu oleh gambar lagi. Salah satu gambar yang digunakan

\footnotetext{
${ }^{57} \mathrm{Ma}^{\prime}$ aruf, Wawancara, Dompu, 22 Agustus 2019.

${ }^{58}$ Erma, Wawancara, Bima, 1 Oktober 2019.
} 
adalah gambar media binatang seperti kuda, kerbau, laba-laba dan harimau. Dalam kegiatan ini yang digunakan kartu-kartu kalimat serta papan slip atau flanel." 59

Anak membutuhkan metode yang menarik dalam belajar membaca. Salah satu media yang digunakan adalah media gambar binatang. Metode ini dapat dinyatakan berhasil apabila menggunakan media yang efektif. Dengan menggunakan media gambar binatang dan penyediaan poster yang berisikan huruf abjad mampu meningkatkan kemampuan membaca permulaan anak usia dini di TK Ma'aruf.

Berdasarkan hasil wawancara di atas dapat disimpulkan bahwa upaya guru dalam pengenalan membaca permulaan pada anak usia dini dilakukan dengan menggunakan media gambar binatang, seperti gambar binatang kuda, kerbau, sapi, laba-laba serta harimau.

\section{Kendala yang dihadapi oleh Guru Dalam Pengenalan Membaca Permulaan Anak Usia Dini (AUD) dengan Menggunakan Media Gambar Binatang Kelompok B di TK Ma'aruf Desa Lanci Jaya Kecamatan Manggelewa Kab. Dompu}

Melihat rendahnya minat membaca permulaan anak usia dini, maka salah satu cara untuk memudahkan anak belajar lancar membaca adalah dengan menerapkan metode pembelajaran yang sesuai dengan kebutuhan anak. Anak membutuhkan metode yang menarik dalam belajar membaca. Salah satu media yang dugunakan adalah media gambar binatang. Metode ini dapat dinyatakan berhasil apabila menggunakan media yang efektif. Meskipun telah banyak upaya guru dalam mengenalkan membaca permulaan terdapat beberapa kendala. Seperti yang dikatan sama Bapak Ma'aruf, S.Pd selaku kepala sekolah, dibawah ini;

"Memang harus diakui bahwa ada kendala yang dihadapi oleh kami dalam proses pengenalan membaca permulaan, salah satunya adalah anak kurang mengenali huruf. Ketidakmampuan anak dalam mengenal huruf-huruf alfabetis seringkali dijumpai oleh kami. Ketidakmampuan anak dalam mengenali huruf, sulit membedakan huruf besar/ kapital dan huruf kecil serta kebanyakan anak belum mengenal dan menghafal huruf abjad atau angka. Kendala yang dihadapi oleh guru dilatarbelakangi oleh murid itu sendiri." 60

${ }^{59}$ Syamah, Wawancara, Bima, 1 Oktober 2019.

60 Ma'aruf, Wawancara, Dompu, 22 Agustus 2019.

Jurnal Pelang̉i Jurnal pemikiran dan penelitian pendidikan Islam anak Usia Dini 
Media gambar binatang sebenarnya sangat penting karena menjadi alat bantu dalam pengenalan membaca permulaan bagi anak usia dini. Dengan menggunakan media gambar anak dapat menyusun kalimat sederhana. Namun terdapat kendala yang dihadapi oleh guru TK Ma'aruf, seperti yang katakan sama Ibu Erma, S.Pd, dibawah ini;

“Kendala yang paling besar yang dihadapi oleh kami dalam pengenalan membaca permulaan adalah banyak anak yang tidak mengenali kata, kurang menguasai kata, kurang dorongan orang tua sehingga mempengaruhi pada anak." 61

Kendala yang dihadapi oleh anak usia dini tersebut adalah kendala universal. Dalam artian semua pernah dirasakan oleh guru sebagai pengajar di TK. Seperti yang disampaikan oleh Ibu Syamsah dalam wawancara dibahawah ini;

"Salah satu kendalanya adalah ketidakmampuan anak dalam mengenal huruf-huruf alfabet. Ketidakmampuan anak dalam mengenali huruf,dan kebanyakan anak belum mengenal dan menghafal huruf abjad atau angka sehingga bisa dikatakan kurang lancar membaca" 62

Kendala yang sangat urgen dihadapi oleh Guru TK Ma'ruf adalah masih banyak anak usia dini yang belum mengenal huruf alfabetis atau angka sehingga memperlambat anak dalam proses pengenalan membaca permulaanya.

Jadi berdasarkan hasil wawancara di atas, dapat disimpulkan bahwa kendala yang dihadapi oleh guru dalam pengenalan membaca sebagai berikut; (1) kurang mengenali huruf dan sulit membedakan huruf besar atau kapital dan huruf kecil, (2) kebanyakan anak belum mengenal dan menghafal huruf abjad atau angka, (3) kurang dorongan orangtua.

\section{REFERENSI}

Al-Hafidz Ahsin W, 2006, Bimbingan Praktis Menghafal Al-Qur'an, Yogyakarta: Pustaka Pelajar.

Armida, 2016, Penerepan Media Gambar Dalam Meningkatkan Berbahasa Anak Pada TK Mekarjaya Bengkunat Belimbing Pesisir Barat, Skripsi,

\footnotetext{
${ }^{61}$ Erma, Wawancara, Bima, 1 Oktober 2019.

62Syamah, Wawancara, Bima, 1 Oktober 2019.
} 
Fakultas Tarbiayah IAIN Lampung.

Ayu, Riana Gusti, 2018, Penerapan Media Gambar Dalam Meningkatkan

Kemampuan Berbicara di TK Athfal Lampung, Skripsi, Fakultas

Tarbiyah UIN Lampung.

Azis Abdul, 2016, Meletakkan Fondasi Usia Emas Anak Indonesia, Pola

Pembeljaran PAUD Berkarakter, Klaten: Cempaka Putih.

Creswel, 2016, Research Design, Kualitatif, Kuantitatif, Mixed, Yogyakarta:

Pustaka Pelajar.

Creswel, Research Design, Kualitatif, Kuantitatif, Mixed,

Derry Iswidharmanjaya, 2008, Bila Anak Usia Dini Bersekolah, Jakarta:

PT Elex Media Komputindo.

Fakhruddin, 2010, Sukses Menjadi Guru TK-PAUD, Tips, Strategi, dan

Panduan Pengembangan Praktisnya, Jogjakarta: Being.

Habibi Muazar, 2018, Analisis Kebutuhan Anak usia Dini, Yogyakarta:

Depublish.

Hamalik, 2010, Proses Belajar Mengajar, Jakarta: PT Bumi Aksara:

Itadz, 2008, Memilih, Menyusun dan Menyajikan, Cerita untuk Anak Usia

Dini, Yogyakarta: Tiara Wacana.

Majid dan Puspitasari, 2006, Pendidikan Agama Islam Berbasis Kompeten, Bandung: PT Rosdakarya.

Maleong, 2002, Metodologi Penelitian Kualitatif, Bandung: Remaja Rosada Karya.

Mansur, 2014, Pendidikan Anak Usia Dini dalam Islam, Cetakan Ke-V, Yogyakarta: Pustaka Pelajar.

Mansur, 2014, Pendidikan Anak Usia Dini dalam Islam, Cetakan Ke-V, Pustaka Pelajar: Yogyakarta.

Mansur, 2015, Pendidikan Anak Usia Dini dalam Islam, Bandung: Remaja Rosada Karya.

Muazar Habibi, Analisis Kebutuhan

Nursanti Metasari, 2015, Pengembangan Pembelajaran Media Kartu Pintar Bola Basket Dalam Tehnik Dasar Bola Basket Untuk Anak usia dini, Jurnal, Universitas Negeri Yogyakarta, No.11 Vol.43.

Rahim Farida, 2011, Pengajaran Membaca di Sekolah Dasar, Jakarta: Bumi Aksara.

Rusman, 2010, Model-Model Pembelajaran:Mengembangkan Profesionalisme Guru, Jakarta: PT. Rajagrafindo Persada.

Jurnal Pelangi Jurnal pemikiran dan penelitian pendidikan Islam anak Usia Dini 